\title{
Screening of Cellulolytic Bacteria From White Oyster Mushrom Growth Media
}

\author{
Rina Budi Satiyarti ${ }^{1}$, Marlina Kamelia ${ }^{2}$, Nurhaida Widiani ${ }^{3}$, Dwijowati Asih Saputri ${ }^{4}$, \\ Supriyadi $^{5}$, Deffi Novitasari ${ }^{6}$ \\ \{rinabudisatiyarti@radenintan.ac.id,marlinakamelia@radenintan.ac.id, \\ nurhaidawidiani@radenintan.ac.id\} \\ Universitas Islam Negeri Raden Intan Lampung ${ }^{1}$
}

\begin{abstract}
White oyster mushroom was a member of wood mushrom which had the highest nutrition content. Therefore, consumption of white oyster mushroom (Pleurotus ostreatus) was increasing among the Indonesian community. On the other side, white oyster mushroom plantation leaving waste in the form of growth media, namely baglog. The remaining baglog has not been well utilized. Baglog will be harmful to the environment if it just thrown away. Utilization of residual as bacterial media grwoth could be used to produce reducing sugars enzyme such as Cellulose. The aim of this research was to isolated Celullolytic bacterial Cellulose producing using baglog as growth media. There were 60 bacteria isolates were obtained from three types of baglog age ie 0,2 and 4 months. Celullose activity were characterized by screening on CMC differentiation media screening. There were 23 bacterial isolates had Celullose activity.
\end{abstract}

Keywords: Bacteria,Baglog, Cellulose activity, White oyster mushrom,

\section{Introduction}

Mushrooms are saprophytic plants which live in weathered wood and obtain food ingredients by utilizing organic waste materials in their natural habitat [1]. Oyster mushrooms or hiratake (Pleurotus sp.) is a member of wood mushroom group. It content more variative nutrients than other types of mushrooms. The nutrients are protein, fat, phosphorus, iron, biotin, niacin, thiamin (vitamin B1), and riboflavin (vitamin B2) [2].

The natural habitat of oyster mushrooms lives in weathered wood and growth during rainy season. It most likely growth in soft piles of wood and tree stumps such as sengon, rubber, kapok, dadap, durian wood, and kidamar in the rainy season will be overgrown with oyster mushrooms. Sawdust is a waste material that is underutilized but becomes the main ingredient in the cultivation of oyster mushrooms. Bran and corn flour are also added as sources of carbohydrates, fats, proteins, vitamins, and minerals. Chalk (Calcium carbonate) as a mineral source and regulator of the planting media $(\mathrm{pH})$, and water so that the mushroom mycelia can grow and absorb its food [2].

Many wood industries in Lampung resulting abundant wood wastes. Tree sawdust commonly used as a growing media for oyster mushrooms in Lampung is rubber trees [3]. Rubberwood is a type of wood that is easy to the saw because it has a smooth surface, so it is good for fungal to growth. Oyster mushroom cultivation provides positive aspects of the food, economy, and health. But, there is enhancement of baglog. Baglog is a planting medium that is inserted into the plastic and then made pieces of logs. Baglog mushrooms consist of composition 
of sawdust $68.5 \%$, fine bran $13.5 \%$, gypsum (CaSO4) $0.5 \%$, lime (CaCO3) $3.5 \%$, TSP $0.5 \%$, manure $13.5 \%$, and water [4]. Sawdust as the main composition of oyster mushroom cultivation is one of the substrates that are rich in cellulose.

Cellulose is a linear polymer of D-glucose consisting 1, 4-glycosidic linkage and is also very closely associated with hemicellulose and lignin. Cellulose, hemicellulose, and lignin made lignocellulose component, which involves in physical strength of cell walls. The conversion of cellulose to glucose was highly cost. The conversion costs could be minimized by Cellulotic bacteria [5].

Cellulolytic bacteria is microorganisms that have ability to degrade cellulose into its monomers. Cellulolytic bacteria widely used as carbon source for biofuels, organic chemicals, and good quality nutrition sources for animal feed through food sources [6]. These bacteria are increasingly beneficial in all fields both in terms of the environment and the economy. Therefore, the aim of this research is to screening and isolated cellulotic bacteria from the waste of white oyster mushroom growing media (Pleurotus ostreatus) made from rubberwood sawdust (Hevea brasiliensis Muell. Arg).

\section{Materials and methods}

\section{Materials}

Samples was collected from Karanganyar Subdistrict, South Lampung Regency. The sample will be processed at the Biology Laboratory of the Tarbiyah and Teachers Faculty of Raden Intan Lampung. Material in this research are NA (Nutrient Agar), 70\% alcohol, CMC (Carboxy Methyl Cellulose) - media fence, $0.5 \%$ congo red, distilled water, Gram coloring (Gentian violet, Lugol, Ethyl Alcohol 96\%, and Safranin), immersion oil, extract yeast and powdered gelatin.

\section{Methods}

\section{Sample preparation}

Baglog waste is sorted first by repairing baglog results of post-harvest failure and baglog. Baglog samples were taken from various post-harvest ages including zero months, two months, and four months.

\section{Dilution and Inoculation of Bacterial Isolates}

Isolation was carried out by suspending 1 gram of sample into $9 \mathrm{ml}$ of sterile distilled water which was then shaken and obtained a dilution of $10^{-1}$. This dilution is made $\mathrm{p}$ to the $10^{-}$ ${ }^{5}$ th series, this is to replace the solids of the test bacterial colonies. $1 \mathrm{ml}$ of diluted bacteria were inoculated into three different Petri dishes containing $9 \mathrm{ml} \mathrm{NA}$ media (Nutrient Agar), then incubated for $24-48$ hours at $37^{\circ} \mathrm{C}$. The number of bacterial colonies is less than 30 or more than 300 colonies will be ignored [6]. Bacterial colonies are selected and isolated into new media. This isolate was grown on NA (Nutrient Agar) media for $2 \times 24$ hours at $37^{\circ} \mathrm{C}$ with a scratch method, to obtain pure colonies [7].

\section{Enzymatic Screening}


Bacterial isolates were inoculated on $\mathrm{CMC}$-agar media enriched by incubation for three days at $37^{\circ} \mathrm{C}$. The fourth day the bacterial isolates in $\mathrm{CMC}$ were flooded with $0.1 \%$ congo red solution and pre-incubated for 5 days. The formation of a transparent zone (clear) indicates the activity of cellulase enzymes produced by bacteria. This transparent zone is an indicator that inoculated bacterial isolates are able to use cellulose as a carbon source. This transparent zone (cleared zone) is formed due to the hydrolysis of cellulose to glucose in CMC solid media [6].

\section{Gram staining}

Observation of cell morphology was carried out by the gram coloring technique. Coloring uses four paints, Gentian violet, Lugol, Ethyl Alcohol 96\%, and Safranin [6]. Each painting is sequentially dropped on a bacterial review preparation. The object of observation is placed in a container with a tissue to absorb the remaining water so that it dries easily. Observations were carried out under a microscope with 100x magnification and previously the object was dripped with emersion oil. The coloring results when it shows red bacterial cells are called Gram-negatives. Whereas, bacteria with staining results are purple called Gram-positive [8].

\section{RESULTS AND DISCUSSION}

Isolation and Calculation of Bacteria

The average yield of bacterial abundance from white oyster mushroom growing media (P. ostreatus) in Nutrient Agar (NA) media were described at figure 1. The abundance of bacteria in each sample is given a different code to facilitate reading. Sample A is a 0-month old waste with bacterial abundance reaching 53, 83 on average. Sample B is 2-months old waste with an abundance of 61,96 . Meanwhile, the highest average number is shown by sample $\mathrm{C}$ which reaches 94,6 .

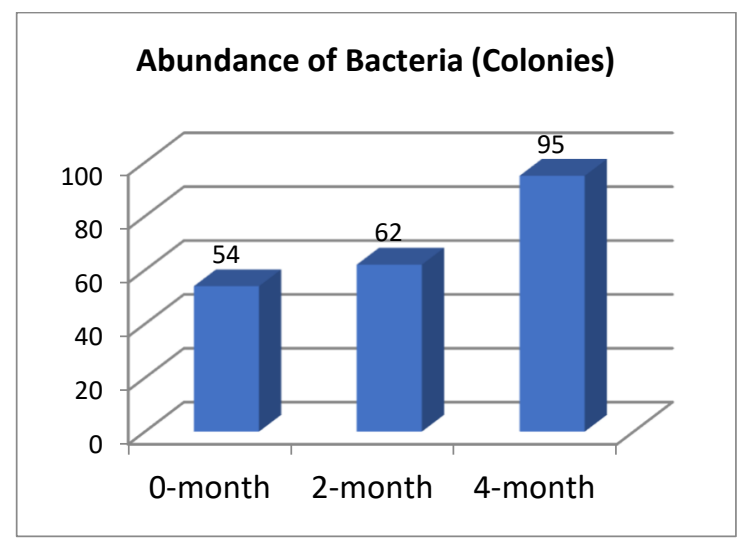

Fig. 1. Number of Bacterial Colonies at Different Baglog Age

\section{Bacterial screening}

Characterization of bacterial isolates includes cellulolytic testing (screening) and Gram staining. Detection of cellulotic bacteria were shown by clear zones in CMC media. Thus bacteria were 
marked by gram staining. Screening data were presented by distinguishing the age of the sample in the form of baglog waste. The results were shown as table 1, table 2, and table 3. Degraded cellulose is then useful for the growth of white oyster mushrooms. Data in a study give assumption that cellulose degradation reaches its peak when white oyster mushrooms form a fruiting body. The abundance of microbes at a high waste age of 4 months were given the best Cellulase activity.

Table 1. Positive Cellulolytic Isolates using Baglog 0 months

\begin{tabular}{cll}
\hline Macroscopic Characteristics (Colonies) & \\
\hline Colour & & \\
1. & Yellow & 4 isolate \\
2. & White & 3 isolate \\
Form & & \\
1. & Round & 3 isolate \\
2. & Undulate & 1 isolate \\
3. & Irreguler & 3 isolate \\
Edge & & \\
1. & Flat & 3 isolate \\
2. & Irreguler & 4 isolate \\
Texture & & \\
1. & Slick & 5 isolate \\
2. & Smooth & 2 isolate \\
Microscopic Characteristics & \\
\hline Staining Gram & \\
1. Gram positif Bacteria & 4 isolate \\
2. Gram negative Bacteria & 3 isolate \\
Form of Bacteria & \\
1. $\quad$ Basil & 2 isolate \\
2. & Coccus & 5 isolate \\
\hline
\end{tabular}

Table 2. Positive Cellulolytic Isolates using Baglog 2 months

\begin{tabular}{|c|c|c|}
\hline \multicolumn{3}{|c|}{ Macroscopic Characteristics (Colonies) } \\
\hline \multicolumn{3}{|l|}{ Colour } \\
\hline 1. & Yellow & 3 isolate \\
\hline 2. & White & 6 isolate \\
\hline \multicolumn{3}{|l|}{ Form } \\
\hline 1. & Round & 3 isolate \\
\hline 2. & Undulate & 5 isolate \\
\hline 3. & Irreguler & 1 isolate \\
\hline \multicolumn{3}{|l|}{ Edge } \\
\hline 1. & Flat & 3 isolate \\
\hline 2. & Irreguler & 6 isolate \\
\hline \multicolumn{3}{|l|}{ Texture } \\
\hline 1. & Slick & 9 isolate \\
\hline 2. & Smooth & 0 isolate \\
\hline \multicolumn{3}{|c|}{ Microscopic Characteristics } \\
\hline Staining & Gram & \\
\hline
\end{tabular}




\begin{tabular}{cl}
\hline 1. Gram positif Bacteria & 7 isolate \\
2. Gram negative Bacteria & 2 isolate \\
Form of Bacteria & \\
1. Basil & 5 isolate \\
2. Coccus & 4 isolate \\
\hline
\end{tabular}

Table 3. Positive Cellulolytic Bacteria Isolates using Baglog 4 months

\begin{tabular}{rll}
\hline \multicolumn{3}{c}{ Macroscopic Characteristics (Colonies) } \\
\hline Colour & Yellow & 0 isolate \\
1. & White & 6 isolate \\
Form & & \\
1. & Round & 3 isolate \\
2. & Undulate & 3 isolate \\
3. & Irreguler & 0 isolate \\
Edge & & \\
1. & Flat & 2 isolate \\
2. & Irreguler & 4 isolate \\
Texture & & \\
1. Slick & 5 isolate \\
2. & Smooth & 1 isolate \\
Microscopic Characteristics & \\
\hline Staining & Gram & \\
1. Gram positif Bacteria & 4 isolate \\
2. Gram negative Bacteria & 2 isolate \\
Form of Bacteria & \\
1. Basil & 2 isolate \\
2. & Coccus & 4 isolate \\
\hline
\end{tabular}

The most abundant bacteria was from baglog within age 2 months. All of bacterial colonies were capable degrade cellulose in CMC media. It given sign that there is an enzymatic activity. The clear zone was related to the solubility of the Cellulase. The activity of Cellulase was shown as a large clear zones. The diameter of the clear zone produced in the study carried out has a very small and thin size so measurement is difficult. It likely because colonies are too small and close to eah others. The Clear zones obtained from the activity of cellulolytic bacteria can be seen in figure 2.

A productive 2-month baglog period is characterized by uneven thickening of the mycelium. Baglog 2 months old has a fairly heavyweight compared to 4 months sample. The abundance of microorganisms such as bacteria in the 2-month sample is fairly large compared to the baglog of 0 months. Baglog samples of 0 month age showed the lowest bacterial abundance after inoculation on solid NA media. 


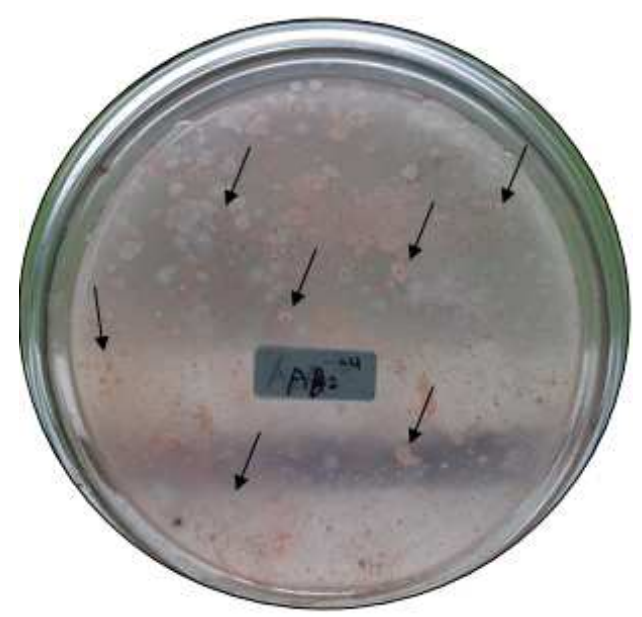

Fig.2. Clear Zone on CMC media

The arrows show clear zone from Celullolytic activity

CMC differential media used for the growth of cellulolytic bacteria. Bacterial colonies that grow faster and wider in $\mathrm{CMC}$ are due to the more abundant ekso- $\beta$-1,4-glucanase enzymes than endo-1,4-glucanase enzymes. Cellulose is a complex enzyme consisting of echob-1,4-glucanase enzymes (cellobiohydrolase), endo-1,4-glucanase (endocellulase) and $\beta$ glucosidase (cellobiase) enzymes. The results of a study explaining that the quantity of ekso- $\beta$ 1,4-glucanase enzymes affects the speed of cellulose degradation. Degraded cellulose is rapidly due to the ability of the echo- $\beta-1,4$-glucanase enzyme to catalyze the formation of cellobiose hydrolyzed to glucose. The low rate of cellulose degradation occurs when more endo-1,4glucanase enzymes are produced which inhibits the formation of glucose as the final product (Nugraha, 2012). Colonies that grow on CMC media can be seen in the figure 3.
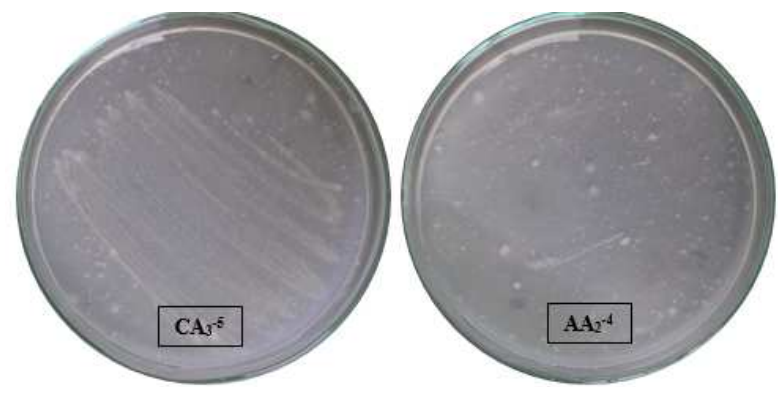

Fig.3. Growth of bacterial colonies on CMC media

The colour and shape of degrading celullose bacteria were undulate white isolates with positive coccus cell forms. The bacterial colony was spreaded in all ages of baglog. Baglog 4-month-old waste sample is an oyster mushroom growing medium that enters the final 
productivity phase. Baglog is said an old baglog when it has the lighter weight characteristics. This lightweight baglog weight is caused by the wood sawdust substrate that is widely used for mycelium growth.

The abundance of baglog waste age 4 months does show the highest amount, but not on the screening results. The results of the screening data showed that the 2-month-old waste had the most cellulolytic abundance compared to other baglog wastes. Cellulolytic organisms that are mostly found in waste aged 2 months were influenced by the nutrient content in baglog. It was because the incubation phase of waste has not been too long so that not many celluloses have been degraded. The availability of cellulose makes the abundance of cellulolytic bacteria quite high compared to baglog for a longer incubation age.

\section{Conclusion}

1. Waste of white oyster mushroom growing media (Pleurotus ostreatus) which made from rubberwood sawdust (Hevea brasiliensis Muell. Arg) has potential to be substrates for cellulolytic bacteria.

2. The 4 months baglog has the highest abundance of bacteria after growing on NA media, due to the high supporting elements of bacterial growth.

3. The form of cellulolytic bacterial isolates are dominated undulate form with irregular white edges and slippery texture. This group of bacteria grows in all baglog waste samples with variations in the presence.

4. The shape of cellulolytic bacterial were in coccus domination.

\section{References}

[1] R. Aziz, "PETUNJUK TEKNIS Budidaya Jamur Tiram (Pleourotus ostreatus var florida) yang ramah lingkungan (Materi Pelatihan Agribisnis bagi KMPH) Susilawati dan Budi Raharjo."

[2] E. M. Sy, Panen jamur tiap musim: panduan lengkap bisnis dan budi daya jamur tiram/Erie Maulana Sy, Ed. 1. Lily Publisher, 2012.

[3] "TV Tani." [Online]. Available: http://tvtani.id/?gclid=CjwKCAiA6vXwBRBKEiwAYE7iS866BMZArFRQwRT1WMcg0P_5p lc10EQoTZOXUArAVBwYTRevKY4rbxoCatYQAvD_BwE. [Accessed: 15-Jan-2020].

[4] N. Hidayat, "Pengaruh Penambahan Kotoran Kambing dan EM4 Terhadap C/N Kompos dari Limbah Baglog Jamur Tiram.".

[5] K. S. AMBRIYANTO and K. SARJU, "ISOLASI DAN KARAKTERISASI BAKTERI AEROB PENDEGRADASI SELULOSA DARI SERASAH DAUN RUMPUT GAJAH (Pennisetum purpureum Schaum)," Undergrad. Thesis, Biol. RSBi 579.3 Amb i, 2010, 2010.

[6] "1 Pusat Penelitian dan Pengembangan Konservasi dan Rehabilitasi - PDF Download Gratis." [Online]. Available: https://docplayer.info/amp/30649613-1-pusat-penelitian-danpengembangan-konservasi-dan-rehabilitasi.html. [Accessed: 15-Jan-2020].

[7] "Jurnal Isdaryanti h411 11 004." [Online]. Available: https://www.scribd.com/document/364247159/Jurnal-Isdaryanti-h411-11-004. [Accessed: 15Jan-2020].

[8] "PEMANFAATAN RESIN KITOSAN-AMIN UNTUK RECOVERY EMAS DARI LIMBAH PENGOLAHAN EMAS," J. Biol. Edukasi, vol. 4, no. 2, pp. 95-99, 2013. 